Wordcount results: 6677

\title{
Trimethylamine abatement in algal-bacterial photobioreactors
}

\author{
Celia Pascual ${ }^{1,2}$, Ilker Akmirza ${ }^{2,3}$, Rebeca Pérez ${ }^{1,2}$, Esther Arnaiz ${ }^{1,2}$, Raúl Muñoz ${ }^{1,2}$, \\ Raquel Lebrero $^{1,2^{*}}$ \\ ${ }^{1}$ Department of Chemical Engineering and Environmental Technology, University of Valladolid, Dr. \\ Mergelina s/n., Valladolid 47011, Spain \\ ${ }^{2}$ Institute of Sustainable Processes, University of Valladolid, Dr. Mergelina, s/n, 47011, Valladolid, \\ ${ }^{3}$ Department of Environmental Engineering, Gebze Technical University, Kocaeli, 41400, Turkey \\ *-Author for correspondence: raquel.lebrero@iq.uva.es
} Spain.

Keywords: Biodegradation, Bubble column bioreactor, Microalgae-bacteria, Odour treatment; Photobioreactor, Trimethylamine.

\begin{abstract}
Trimethylamine (TMA) is an odorous volatile organic compound emitted by industries. Algalbased biotechnologies have been proven as a feasible alternative for wastewater treatment, although their application to abate polluted air emissions is still scarce. This work comparatively assessed the removal of TMA in a conventional bacterial bubble column bioreactor $(\mathrm{BC})$ and a novel algal-bacterial bubble column photobioreactor (PBC). The $\mathrm{PBC}$ exhibited a superior TMA abatement performance compared to the conventional BC. In this sense, the $\mathrm{BC}$ reached a removal efficiency (RE) and an elimination capacity (EC) of $78 \%$ and 12.1 $\mathrm{g} \mathrm{TMA} \mathrm{m}^{-3} \mathrm{~h}^{-1}$, respectively, while the PBC achieved a RE of $97 \%$ and a EC of $16.0 \mathrm{~g}$ TMA $\mathrm{m}^{-3} \cdot \mathrm{h}^{-1}$ at an empty bed residence time (EBRT) of $2 \mathrm{~min}$ and a TMA concentration $\sim 500$ $\mathrm{mg} \mathrm{m}^{-3}$. The outstanding performance of the PBC allow ed to reduce the operating EBRT to 1.5 and $1 \mathrm{~min}$, while maintaining high REs of 98 and $94 \%$, and ECs of 21.2 and $28.1 \mathrm{~g} \mathrm{~m}^{-3} \cdot \mathrm{h}^{-1}$, respectively. Moreover, the $\mathrm{PBC}$ improved the quality of the gas and liquid effluents discharged, showing a net $\mathrm{CO}_{2}$ consumption and decreasing by $\sim 30 \%$ the total nitrogen concentration in the liquid effluent via biomass assimilation. A high specialization of the bacterial community was observed in the PBC, Mumia and Aquamicrobium sp. being the most abundant genus within the main phyla identified.
\end{abstract}




\section{Introduction}

The widespread release of odorous emissions to the atmosphere has become crucial due to their adverse effects on human health and the environment (Xue et al. 2013; Wei et al. 2015). Among odorous compounds, trimethylamine (TMA, $\mathrm{C}_{3} \mathrm{H}_{9} \mathrm{~N}$ ) has been identified as a potentially toxic and likely carcinogenic malodorous volatile organic compound with a low odor threshold concentration of $0.2 \mu \mathrm{g} \mathrm{m} \mathrm{m}^{-3}$ (Chang et al., 2004). Moreover, TMA exerts a detrimental effect on the synthesis of macromolecules such as DNA, RNA and proteins (Liffourrena and Lucchesi 2014), besides inducing teratogenic effects on animal embryos (Kim et al., 2003). TMA is emitted in wastewater treatment and composting facilities, livestock farms and fish meal manufacturing plants; being partially responsible for the unpleasant odor that characterizes these emissions (Chang et al. 2004; Ding et al. 2008). A proper management of TMA-laden emissions according to environmental regulatory limits is crucial not only to avoid safety and health hazards, but also to mitigate environmental impacts (i.e. greenhouse effect, acid rain and eutrophication) (Chang et al., 2004; Perillo and Rodríguez, 2016).

Biotechnologies have been consistently proven as cost-effective and environmentally friendly alternatives to physical-chemical technologies for the abatement of odorous and toxic gas pollutants (Ho et al. 2008; Estrada et al. 2011). Microorganisms belonging to the genera Paracoccus, Hyphomicrobium, Pseudomonas, Methylophilus, Arthrobacter, Aminobacter, Haloanaerobacter and Bacillus are capable of using TMA as the only carbon and energy source (Ding et al. 2008). In addition, previous studies have demonstrated the feasibility of biologically degrading TMA in packed bed bioreactors such as biofilters and biotrickling filters, being the only biotechnology studied up to 
have been achieved in these systems, the accumulation of $\mathrm{NH}_{3}$ (end product of the aerobic oxidation of TMA) typically induces the alkalization of the medium, which ultimately limits TMA biodegradation (Ho et al. 2008). Previous researchers have also evaluated the subsequent $\mathrm{NH}_{3}$ bio-oxidation to nitrite $\left(\mathrm{NO}_{2}^{-}\right)$and nitrate $\left(\mathrm{NO}_{3}^{-}\right)$by heterotrophic bacteria (Oyarzun et al. 2019). However, these nitrogen-containing species remain in the liquid phase resulting in a high nitrogen-loaded effluent.

In the past decades, algal-bacterial based technologies have been widely studied due to their capacity to simultaneously degrading toxic and/or recalcitrant organic materials and depleting nutrients such as ammonium and $\mathrm{NO}_{3}{ }^{-}$at high removal rates (Borde et al. 2003; Muñoz and Guieysse 2006). In this context, processes based on the symbiotic interaction between microalgae and bacteria may constitute a competitive alternative to bacterial-based biotechnologies, where TMA is oxidized by bacteria and the $\mathrm{N}^{-\mathrm{NH}_{3}}$ released from TMA oxidation is fixed by microalgae. Microalgae also fix part of the $\mathrm{CO}_{2}$ produced in the bacterial oxidation of TMA and provide oxygen during the photosynthetic activity, thus reducing the $\mathrm{CO}_{2}$ footprint and the aeration needs of the process (Kang et al. 2017). Moreover, the biomass generated in these processes can be further valorized as biofuel feedstock or as biofertilizer (Muñoz and Guieysse, 2006). Despite the above mentioned advantages, the implementation of algal-bacterial processes for waste gas treatment has been scarcely studied. In this regard, the configuration of the photobioreactor is of key relevance since it determines the efficiency of light penetration in the algal-bacterial cultivation broth. Bubble column reactors guarantee construction and operation simplicity (Chang et al. 2017; Merchuket al. 2007), provide a high mass and heat transfer efficiency, and present low operating costs (Vo et al. 2018; Zhang et al. 2018). 
This research comparatively investigated the TMA removal performance of a bacterial bubble column bioreactor (BC) and an algal-bacterial bubble column photobioreactor (PBC), with a special focus on the quality of the treated gas (TMA and $\mathrm{CO}_{2}$ concentrations) and liquid effluent (concentration of $\mathrm{N}$-containing species). The structure of the microbial community in the PBC was also analyzed by pyrosequencing.

\section{Materials and Methods}

\subsection{Inoculum}

Activated sludge from Valladolid wastewater treatment plant (Valladolid, Spain) was used to inoculate the $\mathrm{BC}$, while a mixed inoculum containing activated sludge and microalgae $(1: 1 \mathrm{v} / \mathrm{v})$ was employed for the inoculation of the PBC. The microalgae were obtained from a biogas upgrading high rate algal pond located at the Department of Chemical Engineering and Environmental Technology at the University of Valladolid (Valladolid, Spain) and operating with a total suspended solids (TSS) concentration of $1.62 \mathrm{~g} \mathrm{~L}^{-1}$ and a volatile suspended solids concentration (VSS) of $1.48 \mathrm{~g} \mathrm{~L}^{-1}$ (FrancoMorgado et al. 2017).

\subsection{Chemicals and mineral salt medium}

The mineral salt medium (MSM) was composed of $\left(\mathrm{g} \mathrm{L}^{-1}\right): \mathrm{Na}_{2} \mathrm{HPO}_{4} \cdot 12 \mathrm{H}_{2} \mathrm{O}, 6.15$; $\mathrm{KH}_{2} \mathrm{PO}_{4}, 1.52 ; \mathrm{MgSO}_{4} \cdot 7 \mathrm{H}_{2} \mathrm{O}, 0.2 ; \mathrm{CaCl}_{2}, 0.038$; and $10 \mathrm{~mL} \mathrm{~L}-1$ of a SL4 solution containing (g L $\left.{ }^{-1}\right)$ : EDTA, $0.5 ; \mathrm{FeSO}_{4} \cdot 7 \mathrm{H}_{2} \mathrm{O}, 0.2 ; \mathrm{ZnSO}_{4} \cdot 7 \mathrm{H}_{2} \mathrm{O}, 0.01 ; \mathrm{MnCl}_{2} \cdot 7 \mathrm{H}_{2} \mathrm{O}$,

0.003. All the chemicals used for the preparation of the MSM were purchased in Panreac (Barcelona, Spain). Trimethylamine (45\% purity) was obtained from Sigma Aldrich (San Luis, EEUU). 
109 The experimental setup (Fig. 1) consisted of two cylindrical PVC columns (height = $1100.58 \mathrm{~m}$; inner diameter $=0.094 \mathrm{~m}$ ) with a working volume of $4 \mathrm{~L}$. The synthetic 111 contaminated emission was prepared by injecting the TMA liquid solution with a 112 syringe pump (Fusion 100, Chemyx Inc. USA) into an air stream of $2 \mathrm{~L} \mathrm{~min}^{-1}$, resulting 113 in an average inlet concentration of $513 \pm 69 \mathrm{mg} \mathrm{m}^{-3}$ in each bioreactor. The gas stream 114 entered a mixing chamber in order to ensure complete TMA evaporation and homogenization before being fed to the reactors through a porous diffuser (pore diameter of $10 \mu \mathrm{m})$ located at the bottom.

117 For the inoculation of the BC, $2 \mathrm{~L}$ of aerobic activated sludge were centrifuged for 10 $118 \mathrm{~min}$ at $10000 \mathrm{rpm}$ and the pellet was resuspended in $1 \mathrm{~L}$ of MSM. The inoculum was 119 added to the BC and fresh MSM was supplemented upon filling the $4 \mathrm{~L}$ of working volume, resulting in TSS and VSS concentrations of 2.79 and $2.13 \mathrm{~g} \mathrm{~L}^{-1}$, respectively. The BC was operated for 78 days at an empty bed residence time (EBRT) of 2 min and a daily replacement of $250 \mathrm{~mL}$ of the culture broth with fresh MSM (equivalent to a dilution rate of $\left.0.0625 \mathrm{~d}^{-1}\right)$. During the first 50 days of operation, all the biomass was

124 recovered from the retrieved cultivation broth by centrifugation and returned to the 125 bioreactor (equivalent to an infinite solids retention time) in order to promote biomass 126 accumulation until reaching $\sim 3 \mathrm{~g} \mathrm{VSS} \mathrm{L}^{-1}$. From day 50 onwards, $75 \mathrm{~mL}$ of the $250 \mathrm{~mL}$ 127 of the cultivation broth daily retrieved were discarded (cell retention time $=53.3$ days) 128 in order to maintain a constant VSS concentration in the bioreactor.

129 A $1 \mathrm{~h}$ abiotic test was performed with no biomass prior PCB start-up. For this purpose, 130 the PCB illuminated with the LED lights was filled with mineral medium and TMA was continuously supplied at an inlet concentration of $\sim 700 \mathrm{mg} \mathrm{m}^{-3}$. The results demonstrated that no TMA was removed by either adsorption or photodegradation 
133 (Supplementary materials, Fig. S1). The inoculation of the PBC was performed by 134 centrifugation of $1 \mathrm{~L}$ of aerobic activated sludge and $1 \mathrm{~L}$ of microalgae culture (10 min, $13510000 \mathrm{rpm})$. The pellets were resuspended in $1 \mathrm{~L}$ of MSM, added to the PBC and filled 136 up to $4 \mathrm{~L}$ with fresh MSM at initial TSS and VSS concentrations of 2.18 and $1.76 \mathrm{~g} \mathrm{~L}^{-1}$, 137 respectively. The $\mathrm{PBC}$ was operated for 103 days. $\mathrm{CO}_{2}$ was added to the inlet TMA138 laden emission at a concentration of $6 \% \mathrm{v} / \mathrm{v}$ in order to supply inorganic carbon for 139 photosynthetic microalgae growth. To this end, $1.88 \mathrm{~L} \mathrm{~min}^{-1}$ of TMA-laden air were 140 mixed with $0.12 \mathrm{~L} \mathrm{~min}^{-1}$ of pure $\mathrm{CO}_{2}$ (Abelló Linde, Spain). A set of LED was installed 141 around the PBC, providing a photosynthetic active radiation (PAR) of $\sim 250 \mu \mathrm{mol} \mathrm{m}^{-2} \mathrm{~s}^{-}$ 1421 at the outer reactor surface. The PBC was operated during the first 54 days at an 143 EBRT of 2 min with a daily MSM exchange rate of $250 \mathrm{~mL}$ (equivalent to a dilution 144 rate of $0.0625 \mathrm{~d}^{-1}$ ) (Stage I). Between days 55 and 79 , the EBRT was reduced to 1.5 min 145 and the MSM exchange rate increased up to $375 \mathrm{~mL} \mathrm{~d}^{-1}$ (Stage II). Finally, from day 80 146 onwards, the EBRT was further decreased to $1 \mathrm{~min}$ and $500 \mathrm{~mL}$ of MSM were daily 147 exchanged (Stage III). During the first 12 days of operation, the biomass was recovered 148 from the withdrawn cultivation broth and returned to the PBC after centrifugation in 149 order to increase VSS concentration in the reactor. From this day on, the amount of 150 biomass returned to the system was adjusted in order to maintain a constant biomass 151 concentration of $3.5 \mathrm{~g} \mathrm{VSS} \mathrm{L}^{-1}$. 


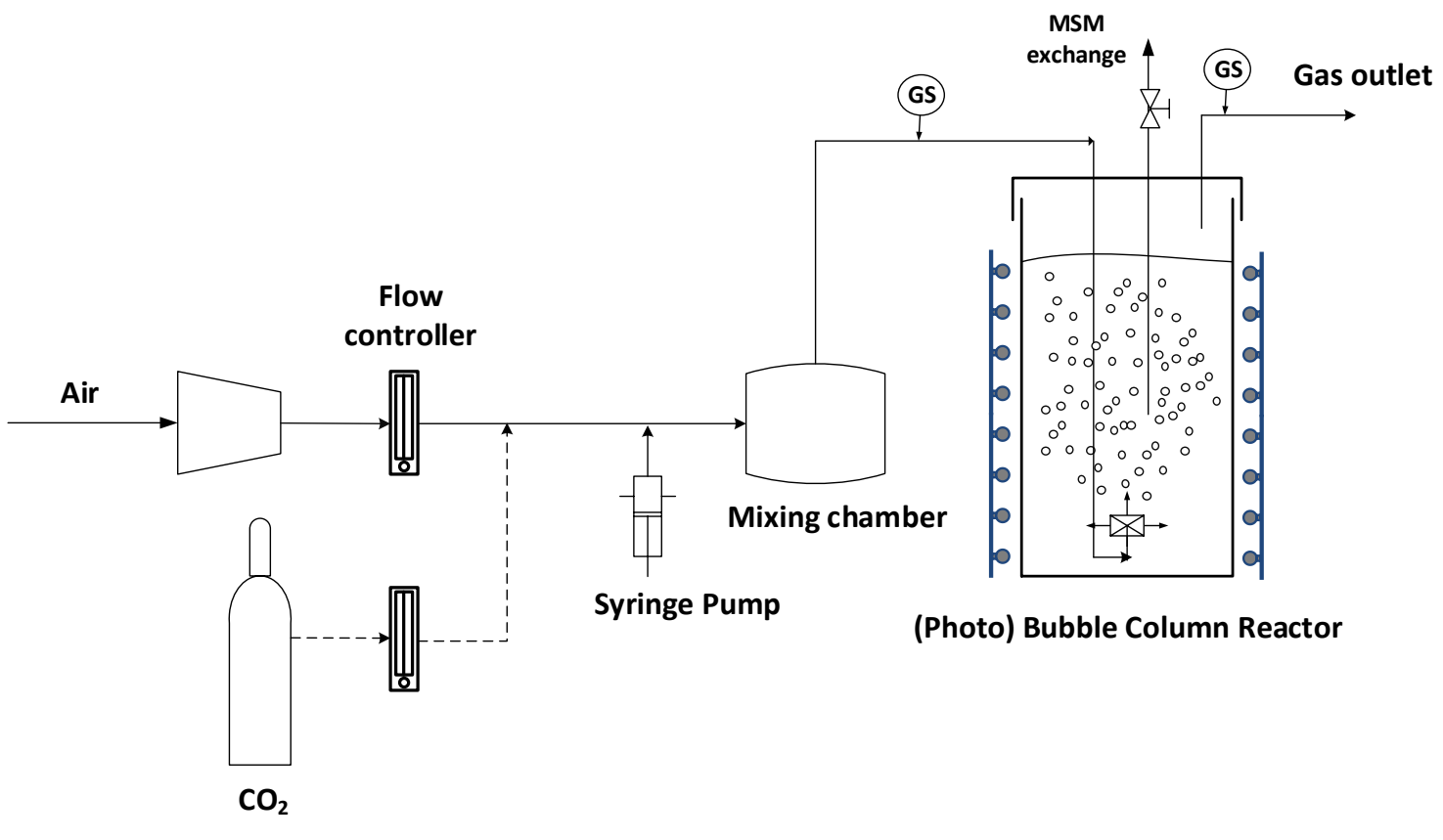

Fig. 1 Schematic representation of the experimental setup. GS: Gas sampling port

TMA gas concentration was analyzed in a Bruker 3900 gas chromatograph (Palo Alto, $\mu \mathrm{m} \times 0.25 \mu \mathrm{m})$ column. The oven, detector and injector temperatures were maintained constant at 250,300 and $200{ }^{\circ} \mathrm{C}$, respectively, for $2.5 \mathrm{~min} . \mathrm{N}_{2}$ was used as the carrier gas at a flow of $1 \mathrm{~mL} \min ^{-1} \cdot \mathrm{CO}_{2}$ and $\mathrm{O}_{2}$ gas concentrations were determined in a Bruker 430 gas chromatograph (Palo Alto, USA) coupled with a thermal conductivity detector and equipped with a CP-Molsieve $5 \mathrm{~A}(15 \mathrm{~m} \times 0.53 \mu \mathrm{m} \times 15 \mu \mathrm{m})$ and a PPoraBOND Q $(25 \mathrm{~m} \times 0.53 \mu \mathrm{m} \times 10 \mu \mathrm{m})$ columns. Oven, detector and injector 163 temperatures were maintained constant at 45,200 and $150{ }^{\circ} \mathrm{C}$ for $5 \mathrm{~min}$, respectively. Helium was used as the carrier gas at a flow of $13.7 \mathrm{~mL} \mathrm{~min}-1$. The pressure in the inlet gas stream was daily measured using a differential pressure sensor IFM (Essen, Germany) in order to control the actual flow of the inlet gas into the reactor. 
167 The $\mathrm{pH}$ was daily analyzed in the cultivation broth using a glass membrane electrode

168 PH BASIC 20 (Crison, Barcelona, Spain). Dissolved oxygen (DO) and temperature 169 were also analyzed in the cultivation broth of the PBC using a CellOx 325 oxygen meter 170 with a temperature sensor (WTW, New York, EEUU). Samples of the liquid phase of 171 both bioreactors were drawn twice a week for the determination of TSS, total organic 172 carbon (TOC), inorganic carbon (IC), total nitrogen (TN), ammonia $\left(\mathrm{NH}_{4}{ }^{+}\right), \mathrm{NO}_{2}^{-}$and $173 \mathrm{NO}_{3}^{-}$concentrations. TSS and VSS concentrations were determined according to 174 standard methods (American Water Works Association, 2012). TOC, IC and TN 175 concentrations were measured using a TOC-VCSH analyzer coupled with a TNM-1 176 chemiluminescence module (Shimadzu, Japan). $\mathrm{NH}_{4}{ }^{+}$concentration was analyzed with 177 an Orion Dual Star ammonium specific electrode (Thermo Scientific, The Netherlands). 178 Finally, $1 \mathrm{~mL}$ samples of cultivation broth were filtered through $0.22 \mu \mathrm{m}$ filters and analyzed by HPLC-IC for nitrite and nitrate determination using a Waters 515 HPLC pump coupled with a conductivity detector (Waters 432) and equipped with an IC-PAK Anion HC column $(4.6 \times 150 \mathrm{~mm})$ and an IC-Pak Anion Guard-Pak (Waters). Samples were eluted isocratically at $2 \mathrm{~mL} \min ^{-1}$ (at room temperature) with a solution of distilled water/acetonitrile/n-butanol/buffer at $84 / 12 / 2 / 2 \%$ v/v (Muñoz et al. 2013). The determination of the elemental composition of the algal-bacterial biomass in terms of carbon $(\mathrm{C})$, hydrogen $(\mathrm{H})$ and nitrogen $(\mathrm{N})$ content was conducted at the end of the experimental period using a LECO CHNS-932 analyzer.

\subsection{DNA extraction, illumina library preparation and pyrosequencing}

189 Two samples were drawn for biological analysis from the cultivation broth of the PBC: I-PBC (corresponding to the algal-bacterial inoculum) and F-PBC (at the end of the experimental period). Total genomic DNA was extracted from $500 \mu \mathrm{L}$ of sample using 
192 the Fast DNA Spin kit for soil (Biomedical, USA) according to the manufacturer's

193 instructions. DNA concentration was estimated by the Qubit fluorometer from

194 Invitrogen, and the final concentration of the DNA sample was normalized to $5 \mathrm{ng} \mu \mathrm{L}^{-1}$.

195 The extracted DNA was stored at $-20^{\circ} \mathrm{C}$ prior to pyrosequencing. Amplicon sequencing 196 was carried out targeting the 16S V3 and V4 regions (464bp, Escherichia coli based 197 coordinates) with the bacterial primers S-D-Bact-0341-b-S-17 and S-D-Bact-0785-a- A198 21, forward and reverse, respectively, which were chosen according to (Klindworth et 199 al. 2013). Illumina adapter overhang nucleotide sequences were added to the genespecific sequences, thus resulting in the following full-length primers for the analysis: 5TCGTCGGCAGCGTCAGATGTGTATAAGAGACAGCCTACGGGNGGCWGCA

$202 \mathrm{G} \quad(16 \mathrm{~S}$ amplicon PCR forward primer), and 5' 203 GTCTCGTGGGCTCGGAGATGTGTATAAGAGACAGGACTACHVGGGTATCTAATCC (16S amplicon PCR reverse primer). Indexed paired-end libraries were generated using the Nextera XT DNA Sample Preparation Kit (Illumina, San Diego, CA), with a reduced number of PCR cycles (25) using $55^{\circ} \mathrm{C}$ as annealing temperature. Libraries were then normalized and pooled prior to sequencing. Non-indexed PhiX library (Illumina, San Diego, CA) was used as performance control. Samples containing indexed amplicons were loaded onto the MiSeq reagent cartridge and onto the instrument along with the flow cell for automated cluster generation and paired-end sequencing with dual s $(2 \times 300 \mathrm{bp}$ run, MiSeq Reagent Kit v3) (Illumina,

212 San Diego, CA). The pyrosequencing analysis was carried by the Foundation for the Promotion of Health and Biomedical Research of Valencia Region (FISABIO, Spain). 
218 Quality assessment was performed using the PRINSEQ-LITE program (Schmieder and

219 Edwards 2011) applying the following parameters: min_length: 50, trim_qual_right: 30,

220 trim_qual_type: mean and trim_qual_window: 20. After quality assessment, paired-end

221 reads were joined together with the FLASH program (Magoč and Salzberg 2011). The

222 eventual chimeras belonging to PCR artifacts among the sequences were discarded

223 using the USEARCH program (Edgar 2010), and taxonomic assignments were then

224 carried out using the RDP-Classifier from the Ribosomal Database Project (Wang et al.

225 2007; Cole et al. 2009), which is available from the RDP website

226 (http://rdp.cme.msu.edu/ classifier/). Shannon index was calculated using the Vegan

227 library version 2.3e1 (Oksanen et al. 2015). The Krona tool was used to represent

228 relative abundances and confidences within the complex hierarchies of metagenomics

229 classifications (Ondov et al. 2011).

230

231

\subsection{Data analysis}

232

The statistical data analysis was performed using SPSS 20.0 (IBM, USA). The results are given as the average \pm standard deviation. Significant differences were analyzed by ANOVA and post-hoc analysis for multiple group comparisons. Differences were considered to be significant at $\mathrm{p} \leq 0.05$.

\section{Results and discussion}

\subsection{Performance of the bacterial bioreactor}

TMA removal efficiency $(\mathrm{RE})$ reached values of $\sim 80 \%$ immediately after BC start-up, recording an average removal of $78 \pm 5 \%$ during the complete experimental period 
(Fig. 2A, white bars). The maximum RE (88.3\%) was observed by day 52 of operation,

242 corresponding to an inlet TMA concentration of $658 \mathrm{mg} \mathrm{m}^{-3}$. The average elimination capacity (EC) of the system was $12.1 \pm 2.2 \mathrm{~g} \mathrm{TMA} \mathrm{m}^{-3} \mathrm{~h}^{-1}$, and the maximum EC value

$245 \mathrm{mg} \mathrm{m}^{-3}$.

A
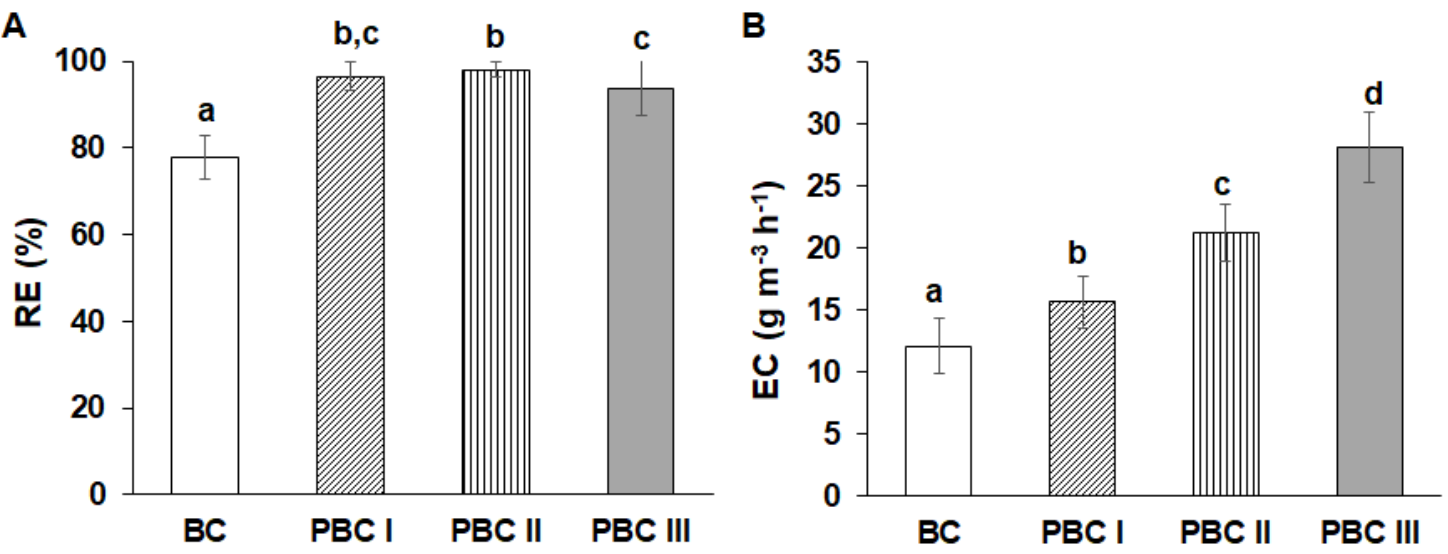

Fig. 2 Average TMA removal efficiencies (A) and elimination capacities (B) in the BC (white bars) and the PBC at the three EBRTs tested: (I) $2 \mathrm{~min}$, (II) $1.5 \mathrm{~min}$ and (III) $1 \mathrm{~min}$. Vertical lines represent standard deviation from replicate measurement under steady state. Columns within each group with different letters were significantly different at $p<0.05$

A high $\mathrm{CO}_{2}$ production was recorded right after the start-up of the $\mathrm{BC}$, reaching a maximum concentration of $5.8 \mathrm{~g} \mathrm{~m}^{-3}$ by day 3 of operation. This high production rate (121.9 $\mathrm{g} \mathrm{CO}_{2} \mathrm{~m}^{-3} \mathrm{~h}^{-1}$ ) was attributed to the degradation of both TMA and cell debris and death biomass from the inoculum. From this day on, $\mathrm{CO}_{2}$ concentration gradually decreased until stabilizing at $1.6 \pm 0.7 \mathrm{~g} \mathrm{~m}^{-3}$ from day 27 onwards. The activation of nitrifying bacteria, autotrophic consumers of $\mathrm{CO}_{2}$, likely contributed to the reduction of the emitted $\mathrm{CO}_{2}$, with final production values of $27.9 \mathrm{~g} \mathrm{CO}_{2} \mathrm{~m}^{-3} \mathrm{~h}^{-1}$. 
261 Ammonia was produced during the aerobic degradation of TMA, and its accumulation

262 in the cultivation broth might result in inhibitory effects on the microbial community.

263 Thus, the analysis of the variation of the $\mathrm{pH}$ and the nitrogen species concentration in

264 the liquid phase is of key importance in biological reactors devoted to TMA removal.

265 From day 0 to 10 , the $\mathrm{pH}$ fluctuated between 7 and 8 , this neutral value being likely

266 associated with $\mathrm{NH}_{4}{ }^{+}$accumulation $\left(\mathrm{NH}_{4}{ }^{+}\right.$concentration in the cultivation broth

267 increased up to $365 \mathrm{mg} \mathrm{N}-\mathrm{NH}_{4}{ }^{+} \mathrm{L}^{-1}$ by day 10). This behavior has been previously

268 reported in biofilters treating TMA (Ho et al. 2008). During these days, neither $\mathrm{NO}_{2}^{-}$

269 nor $\mathrm{NO}_{3}{ }^{-}$accumulation was observed (Fig. 3A). Between days 11 and 50, a gradual

270 decrease in the $\mathrm{pH}$ was recorded, reaching a minimum value of 4.21 on day 49 (Fig.

$271 \mathrm{~S} 2 \mathrm{~A})$. This $\mathrm{pH}$ decrease was attributed to the activation of nitrifying bacteria, which

272 mediated the oxidation of $\mathrm{NH}_{4}{ }^{+}$to $\mathrm{NO}_{3}{ }^{-}$up to a maximum value of $830 \mathrm{mg} \mathrm{N}-\mathrm{NO}_{3}{ }^{-} \mathrm{L}^{-1}$

273 by day 45 and triggered the acidification of the cultivation broth. Similarly, Ho et al.

274 (2008) observed an increase in nitrite and nitrate concentration and a decrease in $\mathrm{NH}_{4}^{+}$

275 concentration when species of nitrifying bacteria were inoculated in their biotrickling

276 filter. In our particular case, $\mathrm{NO}_{2}^{-}$accumulation was negligible compared to $\mathrm{NO}_{3}^{-}$

277 accumulation. The concentration of nitrogen species in the culture medium finally

278 stabilized at steady state values of $411 \pm 79 \mathrm{mg} \mathrm{N}-\mathrm{NH}_{4}{ }^{+} \mathrm{L}^{-1}$ and $793 \pm 96 \mathrm{mg} \mathrm{N}-\mathrm{NO}_{3}^{-}$

$279 \mathrm{~L}^{-1}$ (average $\mathrm{pH}$ of $5.4 \pm 0.4$ ). Despite the high concentrations of $\mathrm{NH}_{4}{ }^{+}$and $\mathrm{NO}_{3}{ }^{-}$, no

280 toxic effect was observed on the microbial community, which was able to maintain

281 constant TMA degradation regardless of the $\mathrm{pH}$ of the culture broth.

282 An initial decrease in the VSS concentration was observed due to cell lysis, reaching a

283 minimum value of $1.07 \mathrm{~g} \mathrm{~L}^{-1}$ by day 4 (Fig. S3A). From day 4 onwards, the VSS

284 concentration gradually increased up to a maximum value of $3.74 \mathrm{~g} \mathrm{~L}^{-1}$ by day 45 . 
285 Finally, a steady concentration of $3.0 \pm 0.1 \mathrm{~g} \mathrm{~L}^{-1}$ was maintained by setting a constant 286 solids retention time.
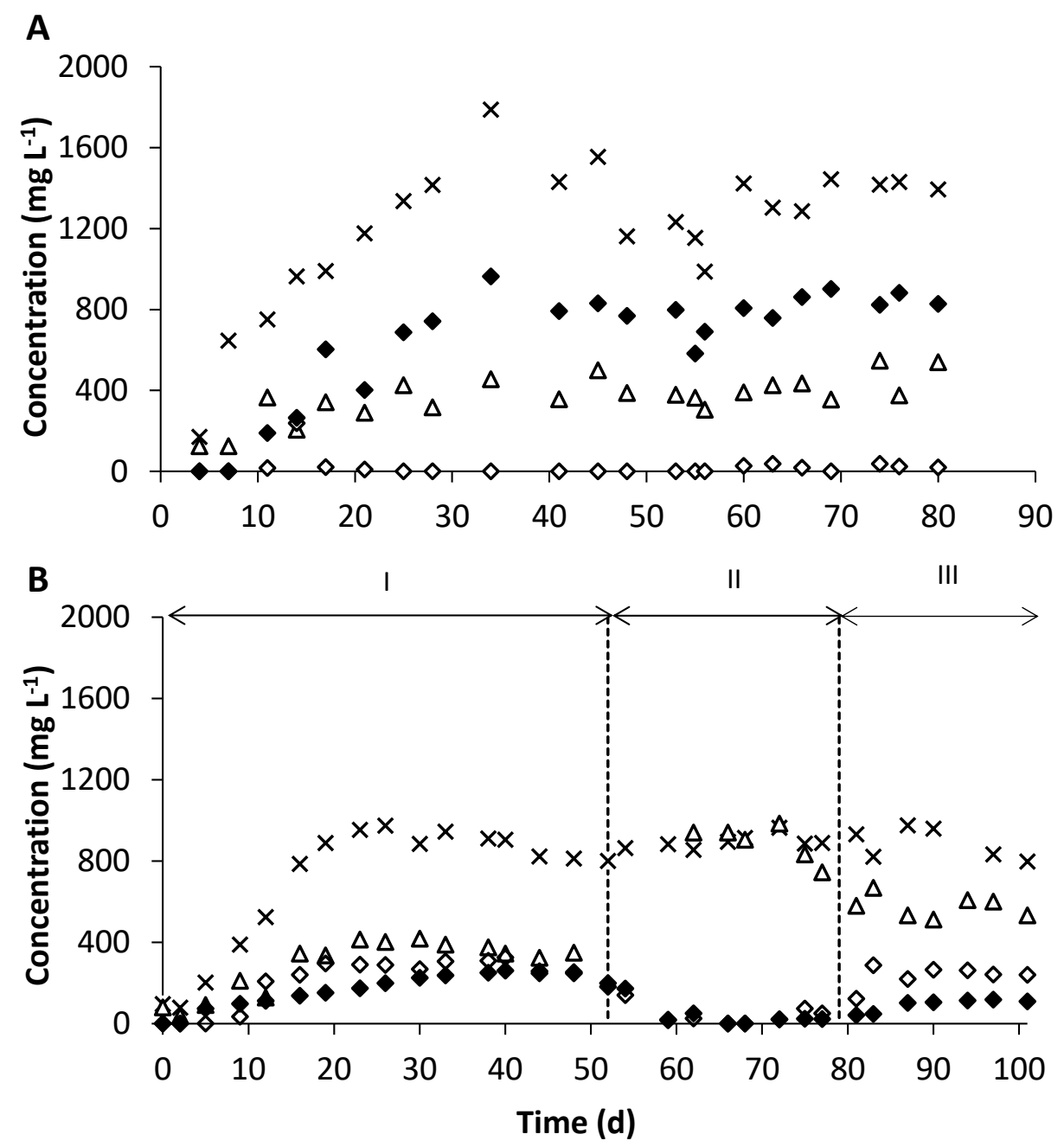

Fig. 3 Time course of the nitrogen species in $\mathrm{BC}(\mathrm{A})$ and $\mathrm{PBC}(\mathrm{B})$ : $\mathrm{TN}(\mathrm{x}), \mathrm{N}-\mathrm{NH}_{4}{ }^{+}(\Delta), \mathrm{N}-$

$$
\mathrm{NO}_{3}{ }^{-}(\bullet) \text { and } \mathrm{N}-\mathrm{NO}_{2}{ }^{-}(\diamond)
$$

\subsection{Performance of the algal-bacterial photobioreactor}

A high TMA removal performance was recorded following PBC start-up. REs and ECs remained at average values of $97 \pm 3 \%$ and $16.0 \pm 2.1 \mathrm{~g} \mathrm{~m}^{-3} \mathrm{~h}^{-1}$, respectively, during process operation at an EBRT of 2 min (Fig. 2). TMA outlet concentrations were significantly lower compared to those recorded in the BC, with average values of $22 \pm$ 
$18 \mathrm{mg} \mathrm{m}^{-3}$. The outlet TMA concentration was even below the detection limit of the

298 GC-FID $\left(\sim 3.6 \mathrm{mg} \mathrm{m}^{-3}\right)$ on certain days of operation. A maximum EC of $18.5 \mathrm{~g} \mathrm{~m}^{-3} \mathrm{~h}^{-1}$

299

300

301

302

303

304

305

306

307 was recorded on day 4, corresponding to a TMA inlet concentration of $655 \mathrm{mg} \mathrm{m}^{-3}$. The good performance of the photobioreactor allowed to further reducing the EBRT to 1.5 min (stage II) and $1 \mathrm{~min}$ (stage III). This decrease in EBRT did not mediate a deterioration in process performance as shown by the high REs of $98 \pm 2 \%$ and $94 \pm 6$ $\%$ recorded in stage II and III, respectively. The increase in TMA load resulted in significantly higher ECs under these operating conditions $(21.2 \pm 2.3$ and $28.1 \pm 2.8 \mathrm{~g}$ $\mathrm{m}^{-3} \cdot \mathrm{h}^{-1}$, respectively) (Fig. $2 \mathrm{~B}$ ). These results were considerably better than those obtained in previous TMA biodegradation studies reported in literature. For instance, Wan et al. (2011) recorded a RE of $\sim 79 \%$ (maximum EC of $14.0 \mathrm{~g} \mathrm{TMA} \mathrm{m}^{-3} \mathrm{~h}^{-1}$ ) in a biotrickling filter treating a contaminated emission polluted with $420 \mathrm{mg} \mathrm{m}^{-3}$ of TMA at an EBRT of $1 \mathrm{~min}$.

A net $\mathrm{CO}_{2}$ consumption of $\sim 9 \%$ (taking into account the $\mathrm{CO}_{2}$ supplemented and $\mathrm{CO}_{2}$ produced by heterotrophic bacteria) was recorded throughout the experimental period as a result of inorganic carbon assimilation by microalgae and nitrifying bacteria. An average $\mathrm{CO}_{2}$ concentration value of $151.8 \pm 21.0 \mathrm{~g} \mathrm{~m}^{-3}$ was obtained regardless of the operating conditions. On the other hand, the outlet $\mathrm{O}_{2}$ concentration always exceeded the inlet concentration value.

$\mathrm{NH}_{4}{ }^{+}$concentration steadily increased after PBC start-up at an EBRT of 2 min, reaching a steady value of $369 \pm 34 \mathrm{mg} \mathrm{N}-\mathrm{NH}_{4}{ }^{+} \mathrm{L}^{-1}$ from day 16 onwards. However, nitrifying activity was recorded earlier in the $\mathrm{PBC}$ compared to the $\mathrm{BC}$, resulting in the accumulation of $\mathrm{NO}_{3}^{-}$and $\mathrm{NO}_{2}^{-}$from days 5 and 9 , respectively. In addition, $\mathrm{NO}_{2}^{-}$ concentration increased above $\mathrm{NO}_{3}{ }^{-}$concentration by day 12 . From day 33 onwards, these nitrogen species stabilized at $290 \pm 33{\mathrm{mg} \mathrm{N}-\mathrm{NO}_{2}}^{-} \mathrm{L}^{-1}$ and $248 \pm 8 \mathrm{mg} \mathrm{N}^{-N_{3}}{ }^{-} \mathrm{L}^{-1}$ 
(Fig. 3B). When the EBRT was reduced to $1.5 \mathrm{~min}$ (stage II), the increase in TMA load resulted in a sharp decrease in the concentration of both nitrite and nitrate to steady values of $48 \pm 27 \mathrm{mg} \mathrm{N}-\mathrm{NO}_{2}{ }^{-} \mathrm{L}^{-1}$ and $22 \pm 2 \mathrm{mg} \mathrm{N}^{-N^{-}}{ }_{3}^{-} \mathrm{L}^{-1}$ during this stage. On the contrary, ammonia concentration increased up to $853 \pm 121 \mathrm{mg} \mathrm{N}-\mathrm{NH}_{4}{ }^{+} \mathrm{L}^{-1}$, which suggested a inhibition of the nitrifying bacteria as a result of their high sensitivity to ammonia loading (Awolusi et al. 2016). A slight recovery of the nitrifying activity was observed during stage III, where ammonia concentration decreased to $593 \pm 60 \mathrm{mg}$ N$\mathrm{NH}_{4}{ }^{+} \mathrm{L}^{-1}$ and nitrate and nitrite concentrations increased to steady values of $111 \pm 6 \mathrm{mg}$ $\mathrm{N}-\mathrm{NO}_{3}{ }^{-} \mathrm{L}^{-1}$ and $252 \pm 23 \mathrm{mg} \mathrm{N}-\mathrm{NO}_{2}^{-} \mathrm{L}^{-1}$, respectively (Fig. 3B).

An average temperature of $30.7 \pm 1.0^{\circ} \mathrm{C}$ was recorded in the PBC cultivation broth, slightly higher than the temperature recorded in $\mathrm{BC}\left(25^{\circ} \mathrm{C}\right)$ due to the illumination of the reactor with LED lights. The DO in the medium remained at $5.7 \pm 0.8,6.7 \pm 0.4$ and $7.2 \pm 0.2 \mathrm{mg} \mathrm{L}^{-1}$ in stages I, II and III, respectively, always below water saturation at the operating temperature $\left(7.6 \mathrm{mg} \mathrm{L}^{-1}\right)$ due to the active aerobic degradation of TMA. The increase in the DO when decreasing the EBRT can be attributed to the higher mass transfer coefficient $\left(\mathrm{K}_{\mathrm{L}} \mathrm{a}\right)$ resulting from the higher gas flowrates, and thereby an enhanced $\mathrm{O}_{2}$ transfer to the liquid medium. Values of DO and $\mathrm{O}_{2}$ concentration in the treated gas stream confirmed that the system was not limited by oxygen availability. The $\mathrm{pH}$ remained roughly constant throughout the complete experimental period, with average values of $6.7 \pm 0.3,7.7 \pm 0.2$ and $7.4 \pm 0.2$ at stages I, II and III, respectively (Fig. S2B).

A decrease in VSS concentration was observed during the first operating days, reaching a minimum value of $1.15 \mathrm{~g} \mathrm{~L}^{-1}$. From day 5, biomass concentration increased up to 3.84 g VSS L-1 by day 12 (Fig. S3B). A daily biomass wastage was then implemented in order to maintain constant VSS concentrations of $3.13 \pm 1.04,4.41 \pm 0.39$ and $3.65 \pm$ 
$3470.61 \mathrm{~g} \mathrm{~L}^{-1}$, in stages I, II and III, respectively. It is important to remark that a higher

348 biomass growth was recorded in the $\mathrm{PBC}$ compared to the $\mathrm{BC}$ due to the contribution of 349 the algal biomass.

\subsection{Comparative analysis between $B C$ and $P B C$}

352

Overall, the PBC showed a better TMA removal performance than the conventional BC at an EBRT of 2 min, with EC $\times 1.3$ times higher compared to those recorded in the BC at this EBRT. This improved behavior was attributed to the higher $\mathrm{pH}$ prevailing in the PBC, which remained close to optimum values (6-8) for the enzymatic activity of TMA-degrading bacteria (Chang et al. 2004). In this context, the $\mathrm{pH}$ in $\mathrm{BC}$ remained below this optimal interval likely due to nitrification, while an average value of $6.7 \pm$ 0.3 was recorded in the $\mathrm{PCB}$ due to $\mathrm{N}$ assimilation by microalgae and the inherent increase in $\mathrm{pH}$ caused by photosynthesis. These favorable environmental conditions allowed reducing the EBRT in the $\mathrm{PCB}$ to $1 \mathrm{~min}$ without statistically significant differences in the RE and higher ECs (up to $\times 2.3$ higher), despite the increase in TMA load. This fact was attributed to a mass transfer limitation rather than a biological limitation in the photobioreactor. In this sense, an increase in the TMA load resulted in a higher concentration gradient and therefore an enhanced TMA mass transfer from the gas to the liquid phase, where TMA-degrading microorganisms were capable of sustaining the removal performance of the system.

Likewise, an improvement in the quality of the liquid effluent in terms of $\mathrm{N}$ content under comparable TMA removal efficiencies was observed in the PBC. A total nitrogen mass balance showed that $30 \%$ less nitrogen was discharged in the exchanged PBC cultivation broth compared to that of the BC, even at EBRTs of 1.5 and 1 min (when TMA load was 1.5 and 2 times higher, respectively) (Fig. 4). TN concentration 
372 decreased significantly from $1307 \pm 149 \mathrm{mg} \mathrm{N} \mathrm{L}^{-1}$ in the $\mathrm{BC}$ to $879 \pm 58,893 \pm 39$ and

$373886 \pm 78 \mathrm{mg} \mathrm{N} \mathrm{L}^{-1}$ in the $\mathrm{PBC}$ in stages I, II and III, respectively. This decrease was 374 associated to nitrogen assimilation during algal biomass growth. Indeed, a biomass 375 production of $\sim 0.23$ and $0.70 \mathrm{~g}$ biomass $\mathrm{d}^{-1}$ was recorded in the $\mathrm{BC}$ and the $\mathrm{PBC}$, 376 respectively. In this context, nitrogen is the most abundant macronutrient in algal 377 biomass with a content ranging between 5 and $10 \%$ of its dry weight, as confirmed by 378 the analysis of $\mathrm{CHN}$ content of algal-bacterial biomass $(42.3 \pm 4.2 \% \mathrm{C}, 6.0 \pm 0.6 \% \mathrm{H}$ 379 and $6.2 \pm 1.3 \% \mathrm{~N})$. Nitrogen can be assimilated in the forms of $\mathrm{NO}_{3}{ }^{-}, \mathrm{NO}_{2}{ }^{-}, \mathrm{NO}$ or $380 \mathrm{NH}_{4}^{+}$, although assimilation of $\mathrm{NH}_{4}{ }^{+}$over nitrite and nitrate is preferred by microalgae 381 as a result of its most reduced redox state (Markou et al. 2014). Interestingly, $\mathrm{NO}_{2}^{-}$ 382 concentration increased in the $\mathrm{PBC}$ during stage $\mathrm{I}$ while an increase in $\mathrm{NH}_{4}{ }^{+}$ 383 concentration was recorded during stage II. This was attributed to the different activity 384 of the bacteria involved in the nitrification process depending on the operating 385 conditions of the $\mathrm{PBC}$, resulting in the inhibition of the different stages of nitrification, 386 where ammonia oxidizing bacteria (AOB) oxidize $\mathrm{NH}_{4}{ }^{+}$to $\mathrm{NO}_{2}{ }^{-}$, which is subsequently 387 oxidized to $\mathrm{NO}_{3}^{-}$by nitrite-oxidizing bacteria (NOB). In this regard, the accumulation 388 of nitrite in stage I was attributed to the partial nitrification of $\mathrm{NH}_{4}^{+}$as a result of the 389 high temperature in the reactor $\left(\sim 31^{\circ} \mathrm{C}\right)$, which could hinder the activity of NOB such as Nitrobacter (optimum temperature range $~ 24-25^{\circ} \mathrm{C}$ ) (Huang et al. 2010; Awolusi et al. 2016). Thus, an incomplete nitrification would trigger the accumulation of $\mathrm{NO}_{2}^{-}$in 392 the medium. On the other hand, $\mathrm{NH}_{4}{ }^{+}$concentration increased in stage II. The higher 393 TMA load applied at this lower EBRT might have inhibited nitrifying bacteria activity 394 due to their greater sensitivity to changes in $\mathrm{NH}_{4}{ }^{+}$loading rates (Hu et al. 2009; Awolusi 395 et al. 2016), thus preventing $\mathrm{NH}_{4}^{+}$nitrification. In stage III, $\mathrm{NO}_{2}^{-}$concentration 
396 significantly increased up to values close to those of stage I, probably due to the 397 acclimation of nitrifying bacteria to the temperature and $\mathrm{NH}_{4}+$ loading rates.

398 Overall, the optimal operating conditions were recorded in the PBC during Stage III 399 since similar values of TMA RE (>90\%) and total nitrogen concentration in the 400 exchanged cultivation broth were recorded compared to Stages I and II, while the TMA 401 elimination capacity increased by $\times 2.3$.

402

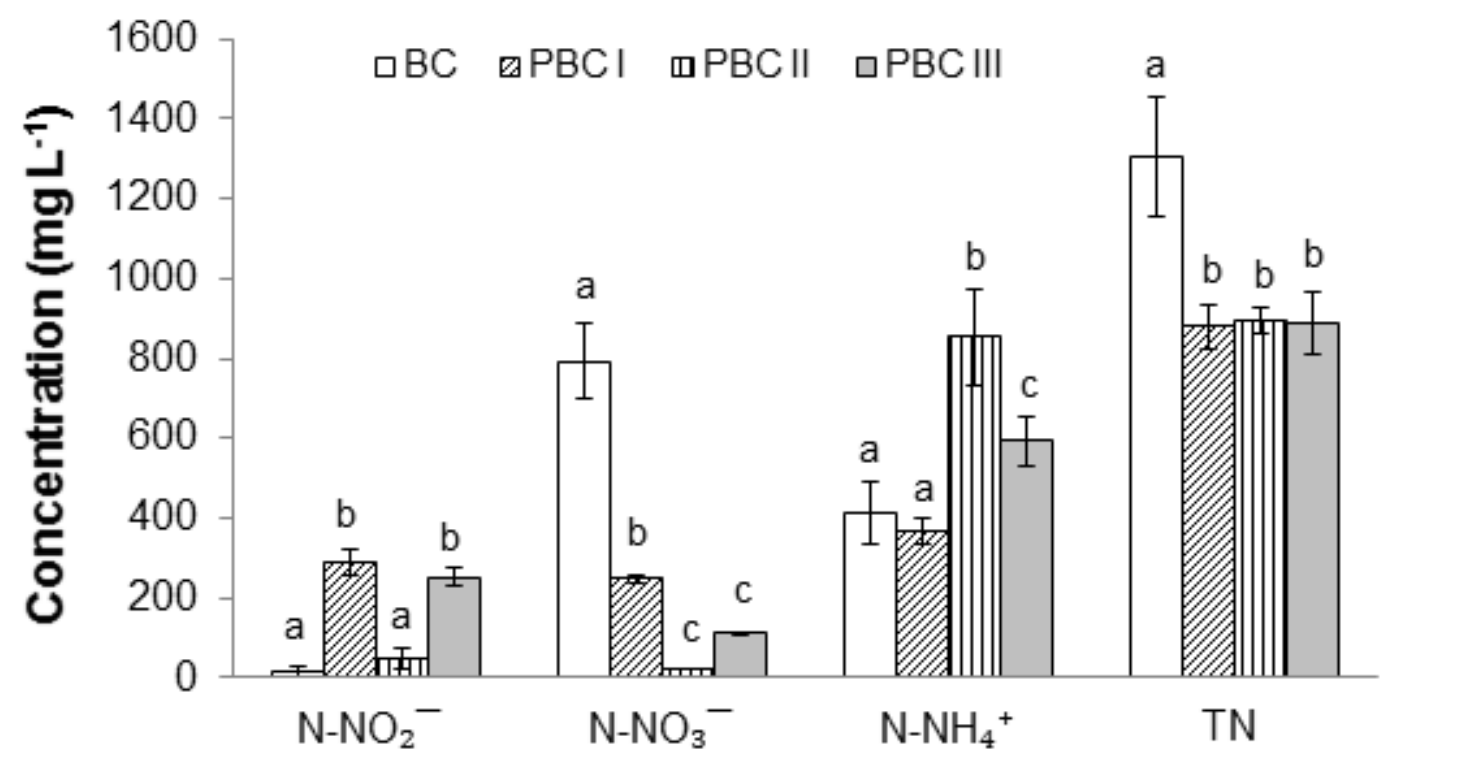

404

405

Fig. 4 Concentration profiles of nitrogen-containing species in the $\mathrm{BC}$ (white columns) and

406 PBC at the three EBRTs tested: (I) 2 min, (II) 1.5 min and (III) 1 min. Vertical lines represent standard deviation. Columns within each group with different letters were signific antly different at $\mathrm{p}<0.05$

\subsection{Effect of trimethylamine on the microbial communities}

411 A total of 133521 and 105547 initial bacterial 16S rRNA sequence reads generated by 412 the MiSeq Illumina platform for I-PBC and F-PBC samples, respectively, passed the quality and taxonomic cutoff. Effective bacterial sequences from the samples were 
414 affiliated to a total of 11 phyla. Of them, the most dominant phyla in I-PBC were

415 Actinobacteria (32\%), Proteobacteria (17\%), Candidatus Saccharibacteria (15\%),

416 Chloroflexi $(11 \%)$ and Firmicutes $(9 \%)$. Other phyla with abundances $>1 \%$ were

417 Bacteroidetes, Planctomycetes and Verrucomicrobia. These phyla are commonly found

418 in activated sludge (Zhang et al. 2012; Lebrero et al. 2013). However, a significant

419 specialization of the microbial community was observed as a result of TMA

420 biodegradation, which resulted in the dominance of only two phyla: Actinobacteria (55

$421 \%$ ) and Proteobacteria (42\%) (Fig. 5). Indeed, the Shannon-Wiener diversity indices of

422 the microbial communities present at the I-PBC and F-PBC were 3.68 and 1.86,

423 respectively. Typical values range from 1.5 to 3.5 , which correspond to low and high

424 species evenness and richness, respectively (MacDonald 2003). The significant decrease

425 in the diversity index revealed a gradual enrichment and specialization of the microbial

426 community as a result of TMA biodegradation.

427

428

429

430

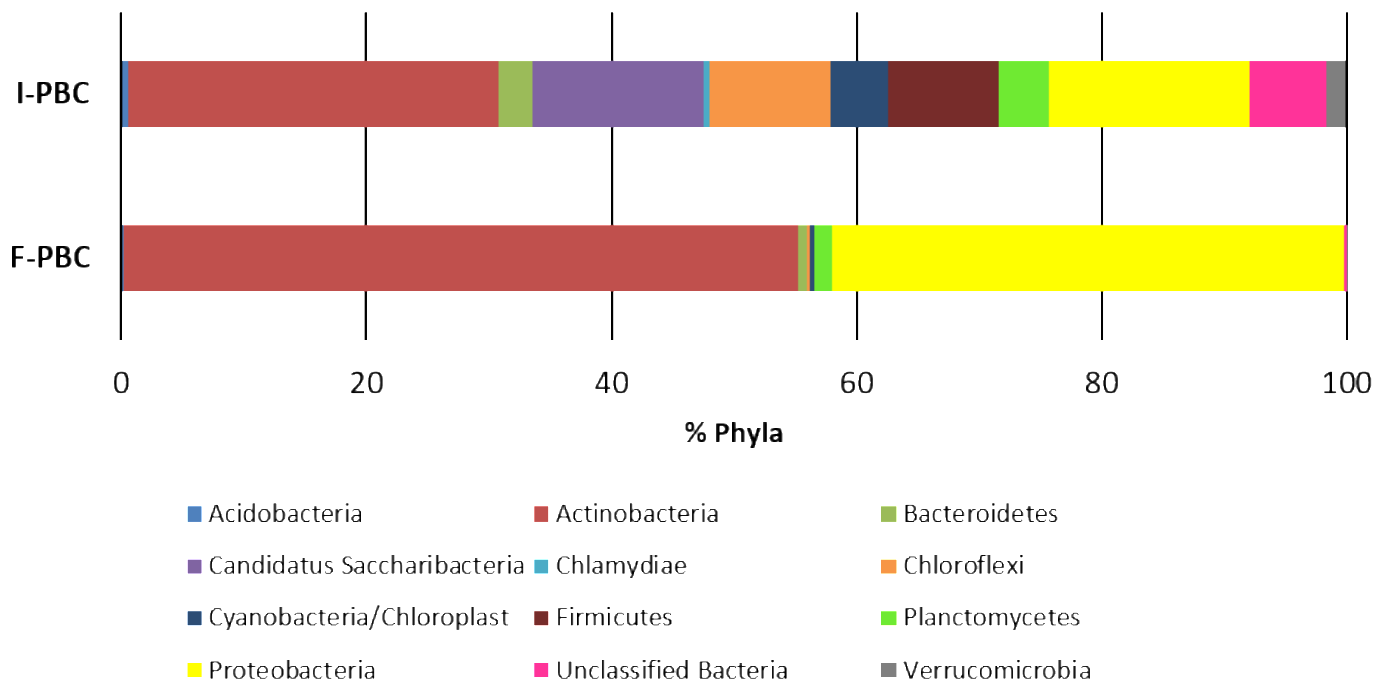

431

Fig. 5 Community composition at a phyla level across samples. I-PBC: algal-bacterial inoculum, F-PBC: end of the experimental period. The abundance is presented in terms of percentage in total effective bacterial sequences in a sample, classified using RDP Classifier 
432 At the genus level, the pyrosequencing showed a total of 501 genera in I-PBC and 139 433 in F-PBC sample (Fig. 6). Of them, only 82 in I-PBC and 20 in F-PBC were present 434 with abundances $>0.1 \%$ (Table S1), and represented 95 and $98 \%$ of the total number 435 of readings at the genus level, respectively, which confirmed the lower diversity in the 436 F-PBC. Based on the phylogenetic analysis, the Actinobacteria phylum was the most 437 abundant in both samples, the genus Mumia, belonging to the family Nocardioidaceae, representing $47 \%$ of the total genera. The Mumia genus was recently discovered in soil samples (Lee et al. 2014), thus growth conditions and functions are yet unknown. The results obtained in the present study suggest the ability of Mumia to grow on TMA, 441 although further research is necessary to confirm this hypothesis.

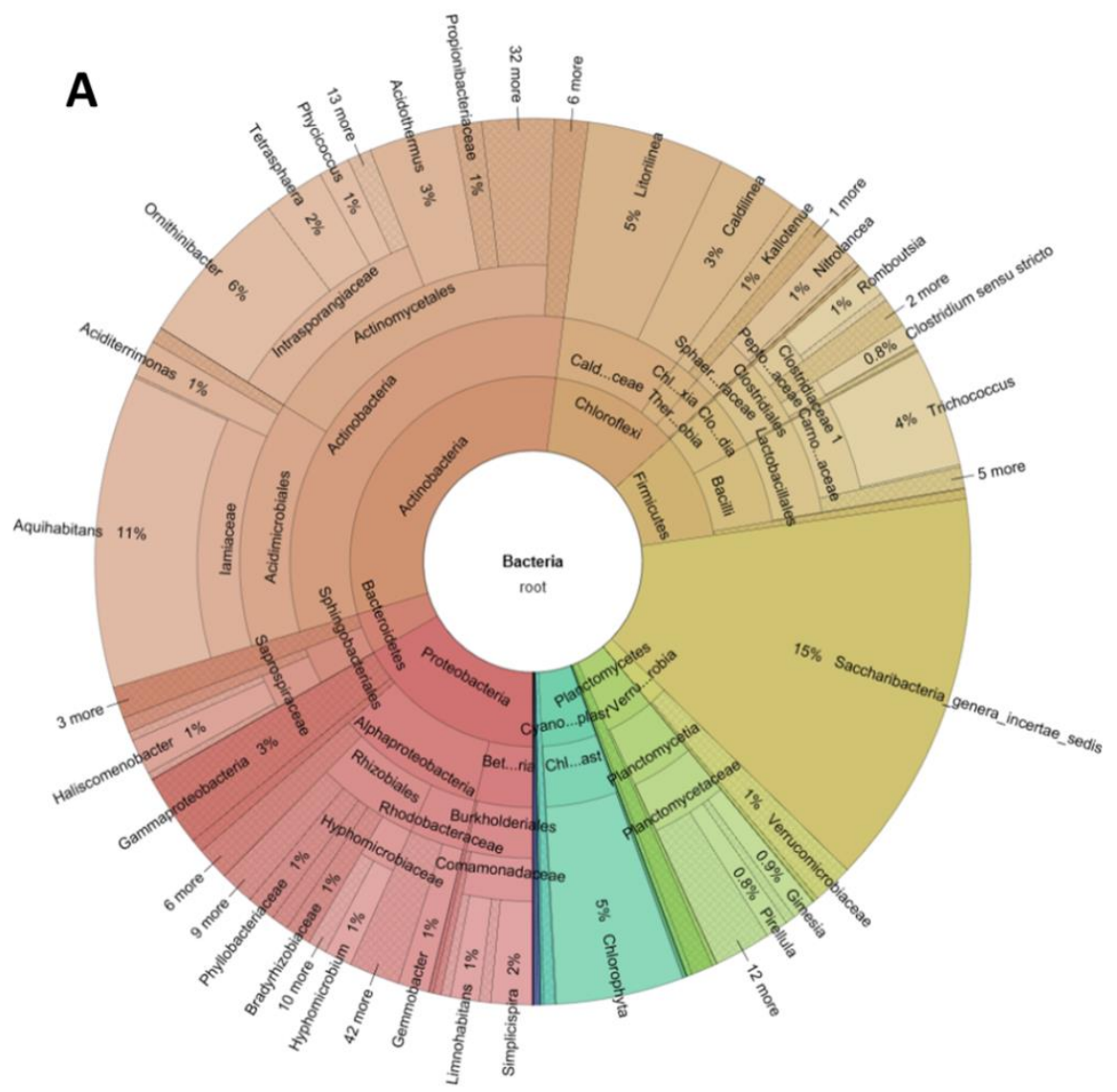




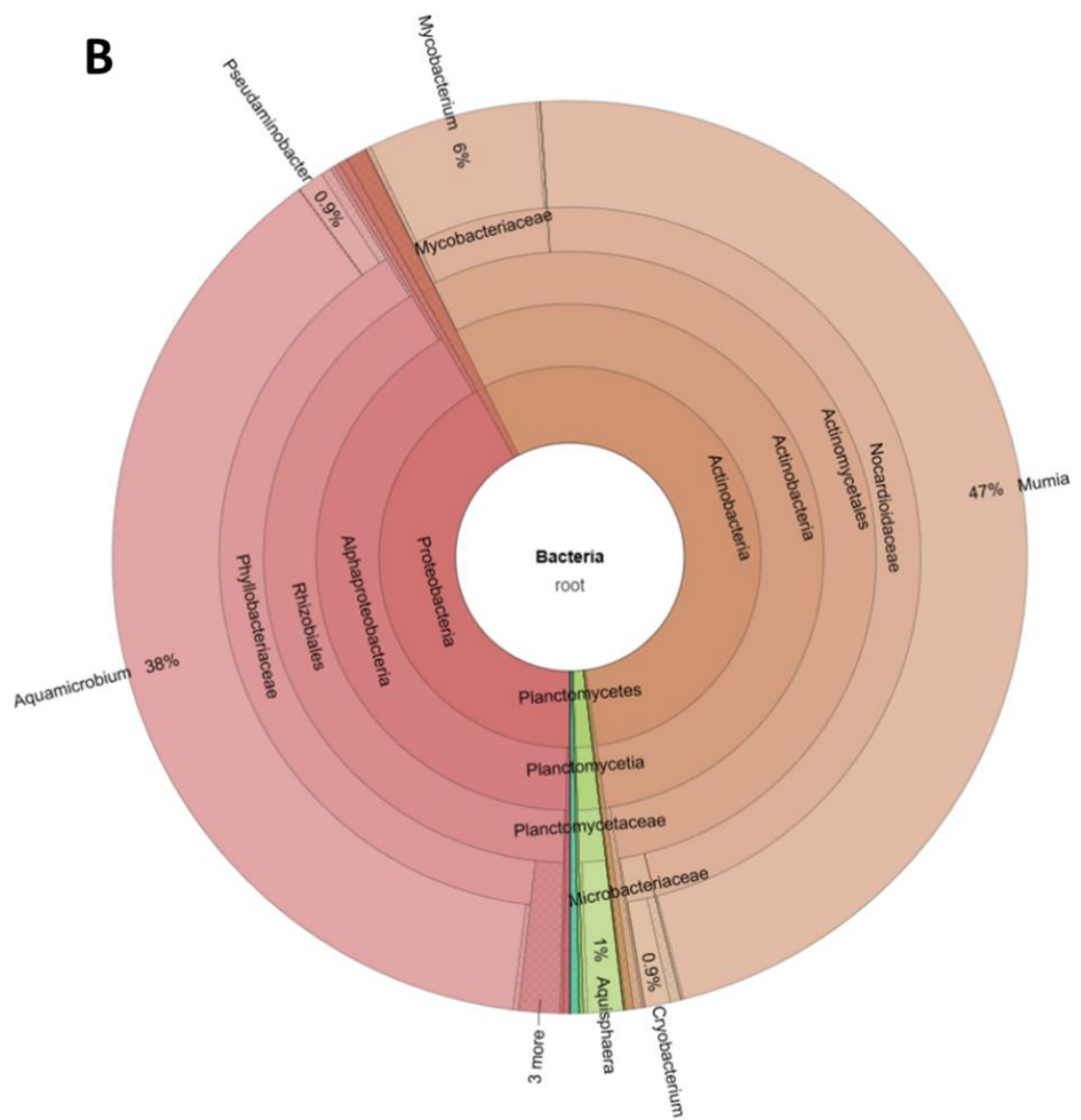

Fig. 6 Krona graphs showing the population structure of samples I-PBC (A: algal-bacterial inoculum) and F-PBC (B, end of the experimental period)

447 The genus Aquamicrobium belonging to the class Alphaproteobacteria showed an 448 abundance of $38 \%$. Different members of the genus Aquamicrobium have been isolated 449 from pollutant-loaded environments such as wastewater treatment plants, activated 450 sewage sludge and biofilters (Jin et al. 2013). Moreover, Aquamicrobium sp. was recently identified as an AOB resistant to high concentrations of $\mathrm{N}_{-} \mathrm{NH}_{4}{ }^{+}$(Yang et al. 2015). Similarly, Huang et al. demonstrated the capacity of Aquamicrobium sp. to 453 oxidize ammonia, and classified this genus as a cold- and salt-tolerant AOB (Huang et 454 al. 2017). Therefore, the presence of Aquamicrobium in the PBC cultivation broth, an 455 AOB extremely tolerant to high temperatures and $\mathrm{NH}_{4}{ }^{+}$concentrations, supports the hypothesis of a partial nitrification which resulted in the accumulation of nitrite over nitrate. 


\section{Conclusions}

460

461

462

463

464

465

466

467

468

469

470

471

472

473

474

475

476

477

478

479

480

481

This study confirmed the feasibility of biologically abating TMA from waste gas streams in bacterial and algal-bacterial bubble column reactors. The bacterial reactor achieved REs of $78 \%$ and ECs of $12 \mathrm{~g} \mathrm{TMA} \mathrm{m}^{-3} \mathrm{~h}^{-1}$ at inlet TMA concentrations of $500 \mathrm{mg} \mathrm{m}^{-3}$ and EBRT of $2 \mathrm{~min}$. Conversely, the algal-bacterial photobioreactor provided enhancements in TMA removal by almost $20 \%$ and reached ECs of $16 \mathrm{~g}$ TMA $\mathrm{m}^{-3} \mathrm{~h}^{-1}$ under similar conditions. The maintenance of high TMA-REs at EBRTs of 1.5 and $1 \mathrm{~min}$ (98\% and $94 \%$, respectively) confirmed the outstanding performance of the algal-bacterial photobioreactor. The higher $\mathrm{pH}$ recorded in the $\mathrm{PBC}$ due to photosynthetic activity together with the lower nitrification rates could have mediated this enhanced performance. Moreover, algal activity in the $\mathrm{PBC}$ resulted in a net $\mathrm{CO}_{2}$ consumption in the gas stream and a $30 \%$ decrease in the TN concentration of the liquid effluent as a result of a superior nitrogen assimilation. These promising results highlight the potential of implementation of this innovative process for TMA abatement from air emissions. Likewise, this study supports the relevance of future research in order to adapt the process to the specific needs of the industrial emissions.

\section{Acknowledgements}

This work was supported by the regional government of Castilla y León and the EUFEDER programme (UIC 71 and CLU 2017-09). 
482

483

484

485

486

487

488

489

490

491

492

493

494

495

496

497

498

499

500

501

502

503

504

505

506

507

508

509

510

511

512

513

\section{References}

Aguirre A, Bernal P, Maureira D, et al (2018) Biofiltration of trimethylamine in biotrickling filter inoculated with Aminobacter aminovorans. Electron J Biotechnol 33:63-67. doi: 10.1016/j.ejbt.2018.04.004

American Water Works Association, 2012.

Standard Methods for the Examination of Water and Wastew ater. American Water Works Association/Americ an Public

Awolusi OO, Nasr M, Kumari S, Bux F (2016) Artificial Intelligence for the Evaluation of Operational Parameters Influencing Nitrification and Nitrifiers in an Activated Sludge Process. Microb Ecol 72:49-63. doi: 10.1007/s00248-016-0739-3

Borde X, Guieysse B, Delgado O, et al (2003) Synergistic relationships in algal-bacterial microcosms for the treatment of aromatic pollutants. Bioresour Technol 86:293-300. doi: 10.1016/S0960-8524(02)00074-3

Chang CT, Chen BY, Shiu IS, Jeng FT (2004) Biofiltration of trimethylamine-containing waste gas by entrapped mixed microbial cells. Chemosphere 55:751-756. doi: 10.1016/j.chemosphere.2003.11.037

Chang J-S, Show P-L, Ling T-C, et al (2017) Photobioreactors. Curr Dev Biotechnol Bioeng. doi: 10.1016/B978-0-444-63663-8.00011-2

Cole JR, Wang Q, Cardenas E, et al (2009) The Ribosomal Database Project: Improved alignments and new tools for rRNA analysis. Nucleic Acids Res. doi: 10.1093/nar/gkn879

Ding Y, Wu W, Han Z, Chen Y (2008) Correlation of reactor performance and bacterial community composition during the removal of trimethylamine in three-stage biofilters. Biochem Eng J 38:248-258. doi: 10.1016/j.bej.2007.07.011

Edgar RC (2010) Search and clustering orders of magnitude faster than BLAST. Bioinformatic s. doi: 10.1093/bioinformatics/btq461

Estrada JM, Kraakman NJRB, Muñoz R, Lebrero R (2011) A Comparative Analysis of Odour Treatment Technologies in Wastew ater Treatment Plants. Environ Sci Technol 45:11001106. doi: 10.1021/es $103478 \mathrm{j}$

Franco-Morgado M, Alcántara C, Noyola A, et al (2017) A study of photosynthetic biogas upgrading based on a high rate algal pond under alkaline conditions: Influence of the illumination regime. Sci Total Environ 592:419-425. doi: 10.1016/j. scitotenv.2017.03.077

Ho KL, Chung YC, Lin YH, Tseng CP (2008) Biofiltration of trimethylamine, dimethylamine, 
and methylamine by immobilized Paracoccus sp. CP2 and Arthrobacter sp. CP1. Chemosphere 72:250-256. doi: 10.1016/j.chemosphere.2008.01.044

Hu J, Li DP, Liu Q, et al (2009) Effect of organic carbon on nitrification efficiency and community composition of nitrifying biofilms. J Environ Sci 21:387-394. doi: Doi 10.1016/S1001-0742(08)62281-0

Huang X, Bai J, Li K ran, et al (2017) Characteristics of two novel cold- and salt-tolerant ammonia-oxidizing bacteria from Liaohe Estuarine Wetland. Mar Pollut Bull 114:192200. doi: 10.1016/j.marpolbul.2016.08.077

Huang Z, Gedalanga PB, Olson BH (2010) Distribution of $<$ I $>$ Nitrobacter $</ \mathrm{I}>$ and $<$ I $>$ Nitrospira $</$ I $>$ Communities in an Aerobic Activated Sludge Bioreactor and their Contributions to Nitrite Oxidation. Proc Water Environ Fed 2010:2390-2403. doi: $10.2175 / 193864710798159101$

Jin HM, Kim JM, Jeon CO (2013) Aquamicrobium aestuarii sp. nov., a marine bacterium isolated from a tidal flat. Int J Syst Evol Microbiol 63:4012-4017. doi:

$$
\text { 10.1099/ijs.0.048561-0 }
$$

Kang D, Zhao Q, Wu Y, et al (2017) Removal of nutrients and pharmaceuticals and personal care products from wastew ater using periphyton photobioreactors. Bioresour Technol. doi: 10.1016/j.biortech.2017.06.153

Kim SG, Bae HS, Oh HM, Lee ST (2003) Isolation and characterization of novel halotolerant and/or halophilic denitrifying bacteria with versatile metabolic pathways for the degradation of trimethylamine. FEMS Microbiol Lett 225:263-269. doi: 10.1016/S03781097(03)00530-5

Klindw orth A, Pruesse E, Schweer T, et al (2013) Evaluation of general 16S ribosomal RNA gene PCR primers for classical and next-generation sequencing-based diversity studies. Nucleic Acids Res. doi: 10.1093/nar/gks808

Lebrero R, Volckaert D, Pérez R, et al (2013) A membrane bioreactor for the simultaneous treatment of acetone, toluene, limonene and hexane at trace level concentrations. Water Res. doi: 10.1016/j.watres.2013.01.041

Lee LH, Zainal N, Azman AS, et al (2014) Mumia flava gen. nov., sp. nov., an actinobacterium of the family Nocardioidaceae. Int J Syst Evol Microbiol 64:1461-1467. doi: 10.1099/ijs.0.058701-0

Liffourrena AS, Lucchesi GI (2014) Degradation of trimethylamine by immobilized cells of Pseudomonas putida A (ATCC 12633). Int Biodeterior Biodegrad 90:88-92. doi: 10.1016/j.ibiod.2014.02.008 
MacDonald G (2003) Biogeography: Introduction to Space, Time, and Life. Prof Geogr. doi: $10.1111 / 0033-0124.5502018$

Magoč T, Salzberg SL (2011) FLASH: Fast length adjustment of short reads to improve genome assemblies. Bioinformatics. doi: 10.1093/bioinformatics/btr507

Markou G, Vandamme D, Muylaert K (2014) Microalgal and cyanobacterial cultivation: The supply of nutrients. Water Res 65:186-202. doi: 10.1016/j.w atres.2014.07.025

Merchuk JC, Garcia-Camacho F, Molina-Grima E (2007) Photobioreactor design and fluid dynamics. Chem Biochem Eng Q 21:345-355.

Muñoz R, Guieysse B (2006) Algal-bacterial processes for the treatment of hazardous contaminants: A review. Water Res 40:2799-2815. doi: 10.1016/j.w atres.2006.06.011

Muñoz R, Souza TSO, Glittmann L, et al (2013) Biological anoxic treatment of O2-free VOC emissions from the petrochemical industry: A proof of concept study. J Hazard Mater 260:442-450. doi: 10.1016/j.jhazmat.2013.05.051

Oksanen J, Blanchet FG, Kindt R, et al (2015) vegan: Community Ecology Package. R package version 2.0-10. 2013. R Packag ver 24-3. doi: 10.1007/s 10265-013-0586-y

Ondov BD, Bergman NH, Phillippy AM (2011) Interactive metagenomic visualization in a Web browser. BMC Bioinformatics. doi: 10.1186/1471-2105-12-385

Oyarzun P, Alarcón L, Calabriano G, et al (2019) Trickling filter technology for biotreatment of nitrogenous compounds emitted in exhaust gases from fishmeal plants. J Environ Manage 232:165-170. doi: 10.1016/j.jenvman.2018.11.008

Perillo PM, Rodríguez DF (2016) Low temperature trimethylamine flexible gas sensor based on TiO2 membrane nanotubes. J Alloys Compd 657:765-769. doi: 10.1016/j.jallcom.2015.10.167

Schmieder R, Edwards R (2011) Quality control and preprocessing of metagenomic datasets. Bioinformatics. doi: 10.1093/bioinformatics/btr026

Vo HNP, Bui XT, Nguyen TT, et al (2018) Effects of nutrient ratios and carbon dioxide biosequestration on biomass growth of Chlorella sp. in bubble column photobioreactor. J Environ Manage 219:1-8. doi: 10.1016/j.jenvman.2018.04.109

Wan S, Li G, Zu L, An T (2011) Bioresource Technology Purification of waste gas containing high concentration trimethylamine in biotrickling filter inoculated with B350 mixed microorganisms. Bioresour Technol 102:6757-6760. doi: 10.1016/j.biortech.2011.03.059

Wang Q, Garrity GM, Tiedje JM, Cole JR (2007) Naïve Bayesian classifier for rapid assignment of rRNA sequences into the new bacterial taxonomy. Appl Environ Microbiol. 
582 Wei Z, Huang Q, Ye Q, et al (2015) Thermophilic biotrickling filtration of gas-phase

583 trimethylamine. Atmos Pollut Res 6:428-433. doi: 10.5094/APR.2015.047

584

Xue N, Wang Q, Wang J, et al (2013) Odorous composting gas abatement and microbial

585 community diversity in a biotrickling filter. Int Biodeterior Biodegrad 82:73-80. doi:

586 10.1016/j.ibiod.2013.03.003

587

Yang X, Liu L, Wu B, et al (2015) [Screening and ammoxidation characteristics of an

588 ammonium oxidizing bacteria group]. Wei Sheng Wu Xue Bao 55:1608-1618.

589

Zhang C, Yuan X, Luo Y, Yu G (2018) Prediction of species concentration distribution using a

590 rigorous turbulent mass diffusivity model for bubble column reactor simulation part I:

591 Application to chemisorption process of $\mathrm{CO} 2$ into $\mathrm{NaOH}$ solution. Chem Eng Sci

592 184:161-171. doi: 10.1016/j.ces.2018.03.031

593

Zhang T, Shao MF, Ye L (2012) 454 Pyrosequencing reveals bacterial diversity of activated

594 sludge from 14 sew age treatment plants. ISME J 6:1137-1147. doi:

595 10.1038/ismej.2011.188

596

597

598

599 